\title{
Livestock Grazing in Afromontane Grasslands in the Northern Bale Mountains, Ethiopia: Implications for Bird Conservation
}

\author{
Addisu Asefa ${ }^{1 *}$, Girma Mengesha ${ }^{2}$, Anteneh Shimelis $^{3}$ and Yosef Mamo ${ }^{4}$ \\ ${ }^{1}$ Ethiopian Wildlife Conservation Authority, Post Box: 386, Addis Ababa, Ethiopia \\ ${ }^{2}$ Wondo Genet College of Forestry and Natural Resources, Post Box: 128, Shashamane, Ethiopia \\ ${ }^{3}$ Department of Zoological Sciences, Addis Ababa University, Post Box: 1176, Addis Ababa, Ethiopia \\ ${ }^{4}$ Department of Biology, Hawassa University, Post Box: 05, Hawassa, Ethiopia
}

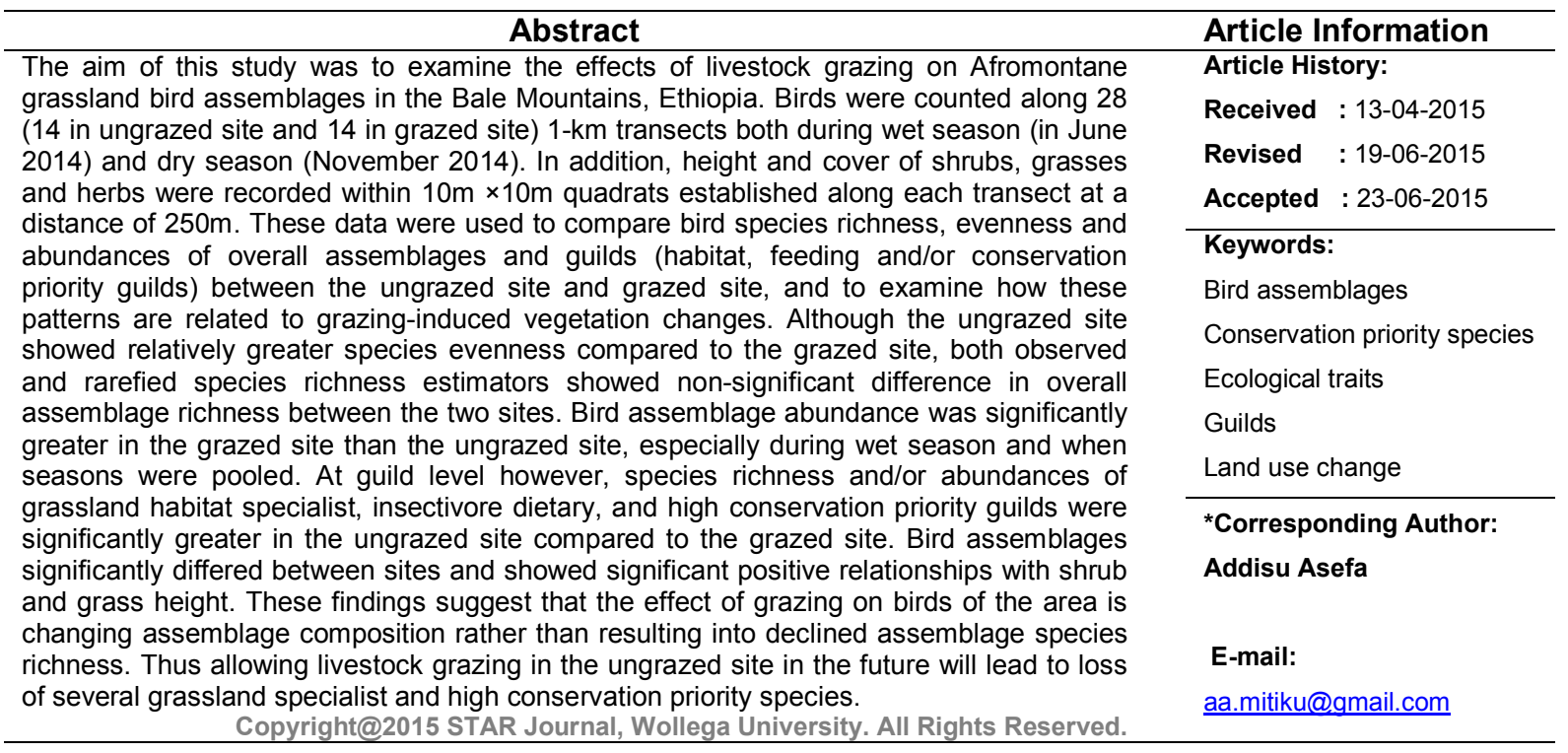

\section{INTRODUCTION}

The degradation and destruction of natural habitats due to human-induced actions are major causes of global biodiversity decline (Brooks et al., 2006; Chown, 2010). This is expected to be increasing in future in developing Tropical countries like Ethiopia, coupled to the everincreasing rate of population growth, where there is a high demand for extensive arable land and grazing areas to meet their basic life needs (Mckee, 2005; Chown, 2010). Understanding the associated threats these actions cause and the way in which plants and animals respond to them is thus important for efficient and effective conservation decision making and management actions (Bleher et al., 2006; Brooks et al., 2006).

Grazing by livestock has been considered to be one of such major factors that lead to habitat alteration in different ecosystems worldwide (e.g. Martin and Possingham, 2005, in Australian woodlands; Whittingham and Devereux, 2008, in grasslands in UK; Yosef Mamo et al., 2014, in Ethiopian Afromotane grasslands). It causes changes in the vertical and horizontal structural composition of vegetation through a combination of trampling, grazing, changes in nutrient fluxes and loss of recruitment (Jensen, 1985; Mclntyre et al., 2003), and facilitates encroachments of non-native species (Kimball and Schiffman, 2003). Further, as a result of the differential responses of different plant species (some respond positively while others respond negatively) to grazing, it can also alter species composition (Rasran et al., 2007; Whitehorn et al., 2011; Yosef Mamo et al., 2014). Such grazing-induced changes in vegetation structure and composition can in turn impact animal diversity, including bird communities. Covering more than $40 \%$ of Earth's land surface, grasslands are the most converted biome due to grazing (Hoekstra et al., 2005), resulting to a more rapid decline in diversity and population of grassland birds than birds of any other habitat type worldwide (Hoekstra et al., 2005; Rahmig et 
Addisu Asefa et alo,

al., 2009). These studies however have found that different species showed widely varying responses and the extent and form of the responses often depend on species-specific ecological traits, including dietary and habitat specialization, and season (Fuller and Gough, 1999; Martin and Possingham, 2005; Evans et al., 2006; Whitehorn et al., 2011). Thus knowledge regarding the ecology and conservation of grassland birds at local level, a scale at which most conservations management decisions are often made, is of important to devise effective management plans.

In this paper we examine the effects on Afromontane grassland bird assemblages of grazing in the Bale Mountains, Ethiopia. The Bale Mountains region is recognized as the centre of endemicity and evolution for several biological taxa (Williams et al., 2004; Addisu Asefa, 2011). It is also one of an Important Bird Area of Ethiopia (EWNHS, 1996). However, this biologically and ecologically important area has been highly altered and degraded due to agricultural expansion, settlement and livestock overgrazing (OBARD, 2007). The northern montane grassland represents a key habitat for several ungulate species, including the endangered endemic mountain nyala (Tragelaphus buxtoni), and of (near) endemic and/or globally threatened birds species such as the Abyssinian long-claw and Rouget's rail (Yosef Mamo et al., 2014). Consequently, most conservation efforts in the Bale Mountains National Park (BMNP) have been concentrated to this area. Despite its immense ecological importance and regular ranger-based law-enforcement activities being carried out in the area, this grassland ecosystem and its associated biodiversity have been threatened mainly by livestock grazing (Stephens et al., 2001; OARDB, 2007; Yosef Mamo et al., 2014).

We have recently shown that livestock grazing in the area has led to reduced cover and height of shrubs and height of grass, but increased covers of grass, grazingweedy herbs and bare ground (Yosef Mamo et al., 2014). It is likely therefore that this grazing-induced vegetation change could affect bird assemblages of the area due to differential responses of species to such habitat change depending on their specific ecological traits, including habitat and dietary requirements. Focusing on two sets of different guilds: (i) habitat guild (i.e., shrub and/or tall grass specialists vs. generalists) and dietary guilds (insectivore, granivore, omnivore and nectarivore), we examined the impact of livestock grazing on avifaunal diversity (i.e. species richness and evenness), population abundance and assemblage composition. We also assessed separately the effects of grazing on species groups considered to be relatively with high conservation priority (i.e. endemic, globally threatened and/or biomerestricted). We predicted that the diversity and abundance of overall avian assemblage and of guilds of species that primarily prefer shrub and/or tall grass habitat and/or are insectivore would be higher in the ungrazed site compared to the grazed site, and vice-versa for habitat generalist.

\section{MATERIALS AND METHODS}

\section{Study Area}

The Bale Mountains region is located in the southeastern highlands of Ethiopia (Figure 1). It is part of the Eastern Afromontane Hotspot Biodiversity area designated by Conservation International (Williams et al., 2004). At the heart of these mountains is the Bale
Sci. Technol. Arts Res. J., April-June 2015, 4(2): 112-121

Mountains National Park (BMNP), which is located at about $400 \mathrm{Km}$ southeast of the capital, Addis Ababa (OBARD, 2007). The national park covers an area of 2200 $\mathrm{km}^{2}$ and ranges in altitude from $1500-4377 \mathrm{~m}$ a.s.I. (OBARD, 2007). To date about 78 species of mammals and 278 bird species have been recorded from the Bale Mountains area; of which 17 mammals and 6 bird species are endemic to Ethiopia (Addisu Asefa, 2007, 2011). The Bale Mountains area is characterized by eight months (March-October) of rainy season and four months (November-February) of dry season (OARDB, 2007). The present study was carried out in the northern montane grassland area which occurs as a central broad flat valley (between altitudes of $3000-3150 \mathrm{~m}$ a.s.l.) between two mountainous ranges (Figure 1). This grassland has an area of $37 \mathrm{~km}^{2}$ of which $\sim 15 \mathrm{~km}^{2}$ is included in the Park (hereafter referred to as ungrazed site) and illegal livestock grazing takes place seldom. The remaining area that falls outside the park is being used as a communal livestock grazing land by the surrounding local community (hereafter referred to as grazed site) (Figure 1; see also OABRD, 2007). On the average, (mean \pm S.D.) $1528 \pm 86$ heads of livestock (cattle and horses) are reported to use the grazed site, respectively, every day (Yosef Mamo et al., 2014).

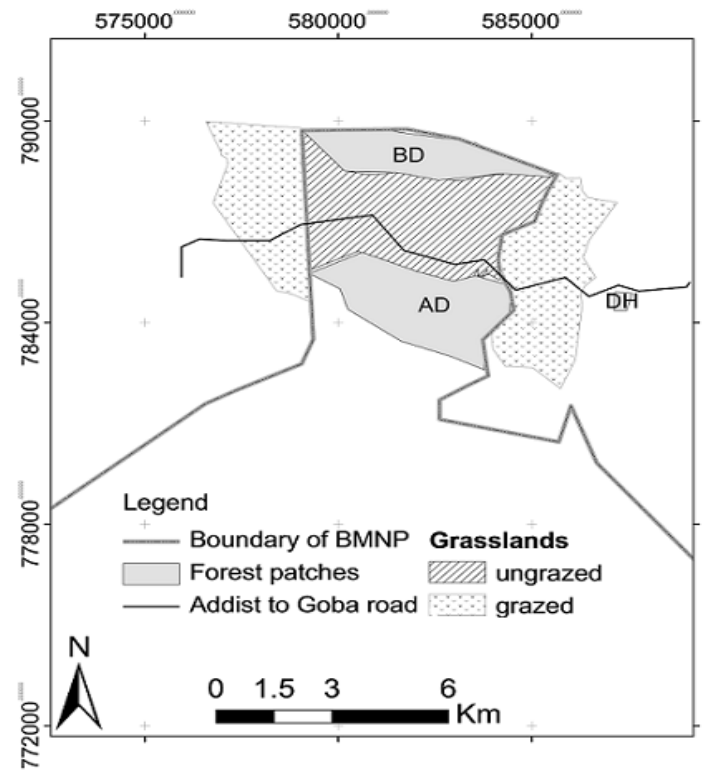

Figure 1: Map of the Bale Mountains National Park (only partly shown) and the ungrazed and grazedthose shown on the east and west of the ungrazed site-grassland sites, and the three forest patches found around the grasslands. Abbreviations of the forest patches: $\mathrm{DH}=$ Dinsho Hill (BMNP HQs); AD = Adellay; \& BD = Boditti.

The vegetation of this grassland is broadly classified in to three types: open grassland (areas covered by short grasses), marsh grassland (characterized by swamp grasses and sedges of Cyperus and Scirpus genera), and shrubland (covered by bushes of Artemesia afra and Helichrysum splendidum) (OARDB, 2007). The extent of the open grasslands is 9 and $15 \mathrm{~km}^{2}$ and of marsh grassland is 10 and $15 \mathrm{~km}^{2}$, respectively, in the ungrazed and grazed sites. Shrublands are completely destroyed in the grazing site and currently occur only in the ungrazed site (Yosef Mamo et al., 2014). Based on 14 altitude measurements taken during this study period using 
Addisu Asefa et alo,

Garmin GPS unit at mid-points of each transect in each land use type, elevation ranges between $3042 \mathrm{~m}-3070 \mathrm{~m}$ a.s.I. (mean $=3056 \mathrm{~m}$ a.s.I.) in the ungrazed site and between $3049-3112 \mathrm{~m}$ a.s.l. (mean $=3091 \mathrm{~m}$ a.s.I.) in grazed site. This montane grassland is considered as a key habitat for several ungulate species, including the endangered endemic mountain nyala (Tragelaphus buxtoni) and other ungulates (OBARD, 2007).

\section{Data Collection}

Bird data were collected in June (wet season) and November (dry season) 2014 along systematically established 28 transects (14 in each land use type and at a minimum distance of $300 \mathrm{~m}$ apart) of each $1-\mathrm{km}$ long, covering $\sim 9 \%$ and $6 \%$ of each vegetation type in the ungrazed and grazed sites, respectively. The start and end geographical coordinates of each transect were saved in Garmin GPS unit to ensure same transects were repeated during the dry season. Birds were counted within $50 \mathrm{~m}$ width on both sides of each transect. All counts (recording of species identity and number of individuals) were made by the same expert observer, early in the morning (between 07:00-10:00) when birds are thought to be more active, while slowly walking at speed of $\sim 2 \mathrm{~km}$ $\mathrm{hr}^{-1}$. Aerial feeders (raptors, swallows and swifts) and wetland birds were not recorded as the primary objective of the study was on terrestrial birds.

To determine the extent to which the two land use types (ungrazed vs. gazed) might differ in their vegetation structure, which in turn might affect avian diversity, vegetation data (heights and percentage covers of plant life-forms [shrub, herb and grass, and percent of bare ground]) were recorded within four $10 \mathrm{~m} \times 10 \mathrm{~m}$ quadrates established along each transects at $200 \mathrm{~m}$ distance intervals. Separate data was recorded for two giant herb species (Ferula communis and Kniphofia foliosa) that grow up to $2 \mathrm{~m}$ high as we thought that their ecological role as bird habitat and food may differ from that provided by small herbs that measure up to $0.5 \mathrm{~cm}$ high. To determine heights of each plant growth forms, four different measurements were taken at each quadrat (totalling to 16 measurements per transect) using a labelled measuring stick and cover was visually estimated (Newton, 2007).

\section{Data Analysis}

Effects of Grazing on Species Diversity and Population Abundance

We used species richness and evenness measures to compare species diversity between the two sites (ungrazed and grazed sites) across the two seasons. Sample-based accumulation curves were compiled for each land use types to determine sampling adequacy by comparing the observed curves with that estimated by appropriate richness estimator. The observed curves were computed using the moment-based interpolation method (i.e. Mao Tau method) in EstimateS package (EstimateS v. 8.2 (http://viceroy.eeb.uconn.edu/estimates) by allowing 500 runs of randomizations without sample replacement, following Colwell (2009). Samples are considered to be adequate if the observed accumulation curves (based on Mao Tau) flatten off at the maximum point the accumulated sample, or if they closely converge with a richness estimator. Estimated richness were computed using all the 10 estimators' available in Esimates package by allowing 500 runs of randomizations with sample replacement (Colwell, 2009). We selected two of the
Sci. Technol. Arts Res. J., April-June 2015, 4(2): 112-121

estimators that provided the lowest (in this case, Chao 1 was chosen) and the highest (Jacknife 2) value of estimated number of species to assess sampling representativeness by comparing them with the observed richness.

To compare total species richness between and across treatments (two sites $\times$ two seasons), the observed sample-based accumulation curves (based on Mao Tau) were rescaled to the number of individuals (Gotelli and Colwell, 2001; Colwell, 2009). Species evenness (a measure of diversity how similar species of an assemblage are in their abundance; higher evenness means more diverse) was also computed in same application using the reciprocal of Simpson diversity index (i.e. as 1/D) (Colwell, 2009). Simpson index was use as it is suggested to be an appropriate measure of diversity for small sample size (Colwell, 2009). However, computation of this diversity index combines information both from number of species and evenness of species abundances of a given assemblage (Magurran, 2004). Thus the reciprocal values Simpson index (1/D) obtained from the EstimateS output for each treatment were divided to the total number of species recorded for each treatment to compute their respective evenness indices (Magurran, 2004). Comparisons of richness, and evenness were made at lower number of individuals recorded in a given treatment category.

Generalized linear model with Poisson probability distribution and log-link function, appropriate for counting data (Quinn and Gough, 2002), was used to assess the effects of grazing, season and their interaction on bird abundance. Finally, one-way ANOVA was used to test the difference in mean abundance between dry and wet seasons within each site and between ungrazed and grazed sites within each season. Both analyses were undertaken in SPSS version 20 statistical package.

\section{Effects of Grazing on Assemblage Composition}

We followed two approaches to examine the effects of grazing on bird assemblage composition: guild composition and multivariate similarity analyses. Prior to analysis we first classified bird species in to two sets of functional guilds based on their habitat and dietary requirements. BirdLife International classifies bird habitats as: artificial terrestrial/aquatic and introduced/exotic vegetation, forest, savannah, shrubland, grassland, rocky areas, caves, desert and several different types of wetlands. The importance of each habitat inhabited by a species was classified as major or suitable (BirdLife International, 2014, http://www.birdlife.org/datazone/info/ spchabalt). For the purposes of this study, species were considered as shrubland and/or grassland specialists, if shrubland and/or grassland were/was recorded as being of major importance to the species; otherwise, were treated as generalists. Species dietary requirement was classified in to four categories, following Addisu Asefa Mitiku (2013) and Gove et al. (2013) as: insectivore (species whose food predominantly constitutes invertebrates), granivore (seed eaters), ominivore (species feeding on insects and plant materials), and nectarivore (species feeding on flower nectar). Detailed information on species-specific habitat, dietary and conservation categories are provided in the Table 1.

Furthermore, although habitat specialists in general are supposed to be more vulnerable to grazing than 
Addisu Asefa et alo,

generalists, some of these specialist species may need relatively greater due attention for conservation actions than others by virtue of their higher local, regional and/or global conservation significance. Thus using three main criteria (which have also been used to select Important Bird Areas globally)—endemicity, biome-restrictedness and global threat status-we assessed if the effects of grazing observed on overall assemblage might also be reflected on conservation concern species (i.e. habitat
Sci. Technol. Arts Res. J., April-June 2015, 4(2): 112-121

specialist species that are of national and/or global conservation concern). Accordingly, habitat specialist species that are endemic to Ethiopia, [highland] biomerestricted and/or globally threatened (critically endangered, endangered, vulnerable or near-threatened; BrdLife International, 2014) were considered as of high conservation significance; otherwise, considered as of low significance.

Table 1: Species recorded during the study period from the Afromontane grasslands in the northern Bale Mountains, southeast Ethiopia and their habitat, dietary and conservation priority categories. (Abbreviations for guild categories are defined as follows; habitat: $\mathrm{spc}=$ specialist, gen = generalist; dietary: insec: insectivore, omn = omnivore, gran = granivore, nect = nectarivore; For site/season: UG DS = ungrazed dry season; UG WS = ungrazed wet season; GR DS = grazed dry season; GR WS = grazed wet season.)

\begin{tabular}{|c|c|c|c|c|c|c|c|c|c|c|}
\hline \multirow[b]{2}{*}{ common name } & \multirow[b]{2}{*}{ scientific name } & \multirow[b]{2}{*}{ habitat } & \multirow[b]{2}{*}{ dietary } & \multirow[b]{2}{*}{$\begin{array}{c}\text { conservation } \\
\text { priority }\end{array}$} & \multicolumn{6}{|c|}{ Site/season } \\
\hline & & & & & $\begin{array}{l}\text { UG } \\
\text { DS }\end{array}$ & $\begin{array}{l}\text { UG } \\
\text { WS }\end{array}$ & $\begin{array}{l}\text { UG } \\
\text { SUM }\end{array}$ & $\begin{array}{l}\text { GR } \\
\text { DS }\end{array}$ & GRWS & $\begin{array}{l}\text { GR } \\
\text { SUM }\end{array}$ \\
\hline $\begin{array}{l}\text { Abyssinian } \\
\text { longclaw }\end{array}$ & Macronyx flavicollis & spe & insec & high & 34 & 30 & 64 & & 7 & 7 \\
\hline $\begin{array}{l}\text { Baglafecht } \\
\text { weaver }\end{array}$ & Ploceus baglafecht & gen & insec & low & & 11 & 11 & & 7 & 7 \\
\hline Cape canary & Serinus canicollis & spe & gran & high & 36 & 23 & 59 & 6 & 234 & 240 \\
\hline Cape crow & Corvus capensis & gen & omn & low & & & & 12 & 32 & 44 \\
\hline $\begin{array}{l}\text { chestnut-naped } \\
\text { francolin }\end{array}$ & $\begin{array}{l}\text { Francolinus } \\
\text { castaneicollis }\end{array}$ & spe & omn & high & & 10 & 10 & & & \\
\hline $\begin{array}{l}\text { cinnamon- } \\
\text { bracken warbler }\end{array}$ & $\begin{array}{l}\text { Bradypterus } \\
\text { cinnamomeus }\end{array}$ & spe & insec & low & 9 & 8 & 17 & & & \\
\hline common fiscal & Lanius collaris & gen & insec & low & & 2 & 2 & & 1 & 1 \\
\hline common quail & Coturnix coturnix & spe & omn & low & & 2 & 2 & & & \\
\hline $\begin{array}{l}\text { common stone- } \\
\text { chat }\end{array}$ & Saxicola torquatus & spe & insec & low & 29 & 45 & 74 & 1 & 2 & 3 \\
\hline common waxbill & Estrilda astrild & spe & gran & low & 11 & 43 & 54 & & 4 & 4 \\
\hline Ethiopian Siskin & Serinus nigriceps & spe & gran & high & 294 & 80 & 374 & 134 & 164 & 298 \\
\hline grassland pipit & $\begin{array}{l}\text { Anthus } \\
\text { cinnamomeus }\end{array}$ & gen & insec & low & & & & 13 & 11 & 24 \\
\hline grey wagtail & motacilla cinerea & gen & insec & low & & & & 15 & & 15 \\
\hline $\begin{array}{l}\text { ground scraper } \\
\text { thrush }\end{array}$ & Turdus litisitsirup & gen & insec & low & 11 & 6 & 17 & 69 & 86 & 155 \\
\hline $\begin{array}{l}\text { Issabelline } \\
\text { wheatear }\end{array}$ & oenathe isabellina & gen & insec & low & 1 & & 1 & & & \\
\hline $\begin{array}{l}\text { malachite } \\
\text { sunbird }\end{array}$ & Nectaniria famosa & spe & nect & low & & 9 & 9 & & 6 & 6 \\
\hline moorland chat & Cercomela sordida & spe & insec & high & 54 & 69 & 123 & 17 & 41 & 58 \\
\hline $\begin{array}{l}\text { moorland } \\
\text { francolin }\end{array}$ & $\begin{array}{l}\text { Francolinus } \\
\text { psilolaemus }\end{array}$ & spe & omn & high & 2 & 3 & 5 & & & \\
\hline $\begin{array}{l}\text { red-billed } \\
\text { oxpecker }\end{array}$ & $\begin{array}{l}\text { Buphagus } \\
\text { erthrorhynchus }\end{array}$ & gen & insec & low & & & & 29 & 8 & 37 \\
\hline $\begin{array}{l}\text { red-breasted } \\
\text { wheatear }\end{array}$ & Oenathe bottae & spe & insec & low & 4 & & 4 & 12 & 7 & 19 \\
\hline $\begin{array}{l}\text { red-throated } \\
\text { pipit }\end{array}$ & Anthus cervinus & gen & insec & low & & & & 31 & & 31 \\
\hline Rouget's rail & Rougetius rougetii & spe & insec & high & 4 & 19 & 23 & & & \\
\hline & $\begin{array}{l}\text { Threkiornis } \\
\text { aethiopicus }\end{array}$ & gen & insec & low & & & & 95 & 19 & 114 \\
\hline $\begin{array}{l}\text { slender-billed } \\
\text { starling }\end{array}$ & $\begin{array}{l}\text { Oegnathus } \\
\text { tenuirostris }\end{array}$ & gen & omn & high & & 2 & 2 & & & \\
\hline $\begin{array}{l}\text { streaky } \\
\text { seedeater }\end{array}$ & Serinus striolatus & spe & gran & high & 25 & 51 & 76 & 2 & 5 & 7 \\
\hline tacazze sunbird & Nectaniria tacazze & gen & nect & low & & 13 & 13 & & 49 & 49 \\
\hline $\begin{array}{l}\text { tawny-flanked } \\
\text { prinia }\end{array}$ & Prinia subflava & spe & insec & low & & 5 & 5 & & & \\
\hline Thekla lark & Galerida theklae & gen & insec & low & 13 & 24 & 37 & 40 & 98 & 138 \\
\hline $\begin{array}{l}\text { thick-billed } \\
\text { raven }\end{array}$ & corvus crassirostis & gen & omn & low & & & & 3 & & 3 \\
\hline wattled ibis & $\begin{array}{l}\text { Bostrychia } \\
\text { carunculata }\end{array}$ & gen & insec & low & & & & 245 & 620 & 865 \\
\hline winding cisticola & Cisticola galactotes & spe & insec & low & 32 & 115 & 147 & 10 & 44 & 54 \\
\hline yellow bishop & Euplectes capensis & spe & gran & low & 80 & 47 & 127 & 3 & 66 & 69 \\
\hline yellow wagtail & Motacilla flava & gen & insec & low & & & & 62 & & 62 \\
\hline
\end{tabular}


Addisu Asefa et alo,

We then computed the sample-based species accumulation curves discussed above for each guild type and used rarefaction curves (rarefied to lowest number of individuals recorded in a site) to compare species richness of each functional guild and conservation significance groups between the grazed and ungrazed sites. We also calculated the proportion each guild contributed to the total number of species and abundances of the bird assemblages in each site. Chisquare was used to test the presence of any significant deviation from expected guild contribution (assuming that each guild would contribute equal proportions to the two assemblages if grazing was absent). All these analyses were conducted by pooling data from the two seasons as number of species and/or individuals for most of the guilds were found to be small to treat seasons separately. Finally, we used two-way crossed ANOSIM (Analysis of similarity) routine in PRIMER software (Clarke and Gorley, 2006) to assess variations in bird assemblage composition between the two sites across seasons (i.e. grazing and season as factors), and one-way ANOSIM to compare between seasons for each site and between sites within each season. A Bray-Curtis similarity index was used to calculate similarities in composition among assemblages; data for each species in each site were first standardized by multiplying the raw values by species' dispersion weight (to minimized the effects of species occurring in large flocks) (Clarke and Gorley, 2006). These standardized values then were square-root transformed beforehand to down-weight common species relative to those that are rare (Clarke and Gorley, 2006). Global R values were used to determine the degree of similarity among treatments. This is a non-parametric permutation procedure applied to rank similarity matrices underlying sample ordinations (Clarke and Gorley, 2006). The closer the value of $R$ value is to 1 , the more dissimilar species assemblages are.

\section{Effects of Grazing-Induced Vegetation Change on Bird Assemblage}

Data on vegetation height and cover were $\log (x+1)$ and arc-sin transformed, respectively, and then were normalized prior to analysis (Clarke and Gorley, 2006). Two-way crossed (using grazing and season as factors) ANOSIM was used to assess the effects of grazing and season on vegetation structure. The results of this analysis showed that only the effect of grazing was significant (Global $R=0.873, P<0.05$ ), but of season was not both within and across grazing treatments. Thus mean values of data for each vegetation variable was calculated from the two seasons and used to assess if the grazingassociated changes in vegetation characteristics affected bird assemblages. The BEST procedure was used to examine this relationship between the multivariate community analysis (e.g. similarity among samples) and that from the habitat variables associated with those samples; the extent to which these two patterns match reflects the degree to which the chosen habitat variables explain the diversity pattern (Clarke and Gorley, 2006). Variable selection was made using a Bio-Env algorithm, which searches all possible combinations from the primary datasheet. Spearman rank correlation $\left(P_{s}\right)$ was used to measure the strength of the relationship between the bird diversity and habitat variables (Clarke and Gorley, 2006). All these analyses were undertaken in Primer software (Clarke and Gorley, 2006).
Sci. Technol. Arts Res. J., April-June 2015, 4(2): 112-121

\section{RESULTS}

Effects of Grazing on Species Diversity and Population Abundance

Sample-based rarefaction curves did almost reach an asymptote, and they did completely overlap with Chao 1 estimator in all cases (indicating 100\% sampling completeness) and did converge closely with the observed Jacknife 2 richness estimator curves (indicating sampling representation of $87 \%$ and $88 \%$ in the grazed site, and $90 \%$ and $92 \%$ for the ungrazed site, respectively, during dry and wet seasons (Table 2). Comparisons between land use types and/or seasons were therefore made based on rarefied (to the lowest number of individuals recorded in a given treatment) number of observed richness (i.e. Sobs based on Mao Tau estimated richness values).

Overall, 1236 observations (611 in the ungrazed site and 625 in the grazed site) were recorded. In total, 33 species were recorded across both land use types during both seasons, of which 24 (16 during the dry season and 22 during the wet season) and 25 species (19 during the dry season and 21 during the wet season) were recorded in the ungrazed and grazed sites, respectively (Table 2; see also the Appendix). Both observed (based on Mao Tau) and estimated (Jacknife 2) species richness values were almost similar between ungrazed and grazed sites either when seasons were pooled or separately compared (Table 2). Independent of site, these values were also similar between seasons (Table 2). Similar results were found when rarefied species richness of sites was compared both within and across season (Table 2. Figure 2 a-d). The $95 \%$ confidence intervals of rarefied species richness of sites did overlap in all cases (Figure 2a-d), indicating the lack of statistically significant difference between sites, as well between season. Nonetheless, the ungrazed site showed relatively greater evenness compared to the grazed site when seasons were treated separately as well when pooled (Table 2 ).

Both grazing and season, and their interaction, had significant effects on the abundance of bird assemblage (grazing Wald $X^{2=}$ 265.622; season, $X^{2}=83.168$; interaction, $X^{2}=73.518$, in all cases, $\left.\mathrm{df}=1, P<0.05\right)$. Independent of season, bird abundance was significantly greater in the grazed site than the ungrazed site, and wet season was significantly greater compared to dry season (Table 2). When each season were separately compared between the two sites, only wet season abundance data for the grazed site was significantly greater than the ungrazed site (Table 2).

\section{Effects of Grazing on Assemblage Composition}

Species richness of grassland habitat specialist guild, insectivore dietary guild, and high conservation priority guild were significantly greater in the ungrazed site compared to the grazed site (in all cases, $P<0.05$ at $\alpha=$ 0.05 ; Table 3). The percentage contribution of the different habitat guilds and conservation significance guilds to the over total richness and abundances of the ungrazed and grazed assemblages were significantly different (richness, habitat guild: $x^{2}=12.93$, df $=3, P<0.05$; conservation priority: $\quad X^{2}=13.075 \quad \mathrm{df}=3, \quad P<0.05$; abundance, habitat guild $=X^{2}=81.016, \quad P<0.05$; conservation priority: $\left.x^{2}=31.631, P<0.05\right)$. Both habitat specialist guild and high conservation priority guild relatively contributed greater proportion to the total richness and abundance of bird assemblage in the ungrazed site compared to the grazed site (Figure 3a-f). 
Table 2: Mean ( \pm S.E) abundance, species richness [based on observed $\left(S_{o b}\right)$, Jacknife 2 estimator $\left(S_{j k}\right)$ and rarefied $\left.\left(\mathrm{S}_{\mathrm{rar}}\right)\right]$ and species evenness of the grazed and ungrazed sites across seasons

\begin{tabular}{|c|c|c|c|c|c|c|c|}
\hline \multirow{2}{*}{ Groups } & \multirow{2}{*}{ Site/season } & \multicolumn{2}{|c|}{ Abundance } & \multicolumn{3}{|c|}{ Species richness } & \multirow{2}{*}{ Evenness } \\
\hline & & $\mathbf{n}$ & Mean ( \pm S.E.) & $\mathrm{S}_{\mathrm{ob}}$ & $\overline{S_{j k}}$ & $\mathbf{S}_{\text {rar }}^{*}$ & \\
\hline \multirow{2}{*}{ dry } & ungrazed & 639 & $43.21( \pm 1.76)^{a}$ & 16 & 19 & 16 & 0.23 \\
\hline & grazed & 799 & $57.07( \pm 1.77)^{a}$ & 19 & 22 & 18 & 0.18 \\
\hline \multirow{2}{*}{ wet } & ungrazed & 617 & $44.07( \pm 1.77)^{\mathrm{a}}$ & 22 & 24 & 22 & 0.45 \\
\hline & grazed & 1511 & $107.93( \pm 2.02)^{b}$ & 21 & 24 & 18 & 0.18 \\
\hline \multirow{2}{*}{ Pooled season } & ungrazed & 1256 & $43.64( \pm 1.25)^{\mathrm{a}}$ & 24 & 26 & 24 & 0.30 \\
\hline & grazed & 2310 & $78.48( \pm 1.72)^{b}$ & 25 & 28 & 23 & 0.23 \\
\hline \multirow{2}{*}{ Pooled site } & dry & 1438 & $49.66( \pm 1.33)^{a}$ & 23 & 26 & 23 & 0.38 \\
\hline & wet & 2128 & $68.97( \pm 1.65)^{b}$ & 26 & 27 & 25 & 0.28 \\
\hline
\end{tabular}

Significant differences in mean abundance of birds between the ungrazed and grazed sites within each season and pooled season, and between seasons (based on pooled sites) are indicated by different superscript letters. * Rarefied species richness represents the number of species at the lowest number of individuals recorded in either of the treatments compared (e.g. 639 individuals for comparison between ungrazed and grazed sites during dry season).

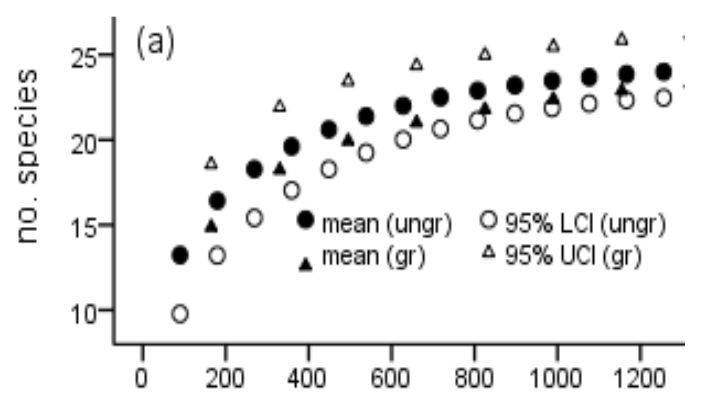

no. individuals

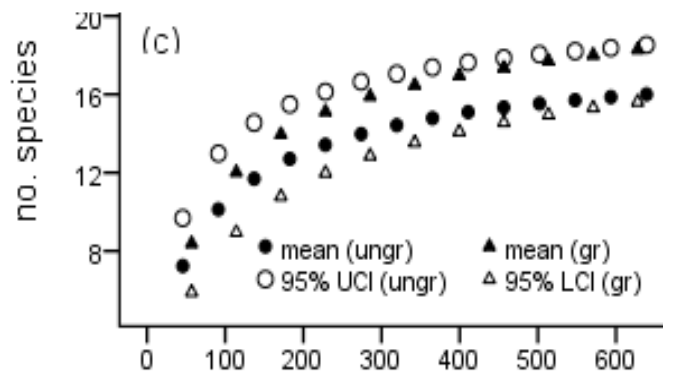

no. individuals
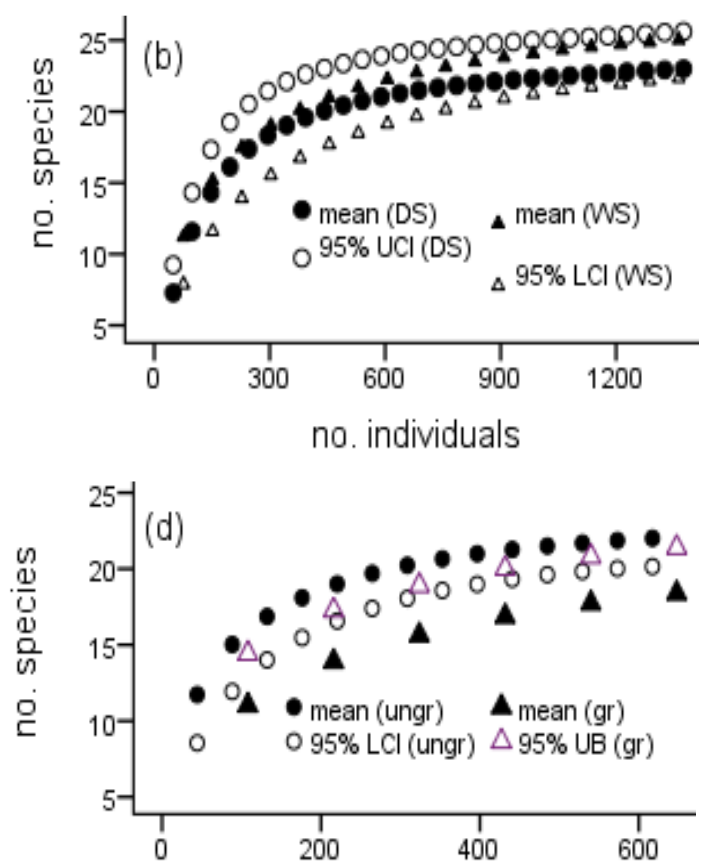

no. individuals

Figure 2: Rarefied species richness (by rescaling the observed Moa Tau sample-based rarefaction curves to number of individuals) of the ungrazed (ungr) and grazed (gr) sites (a), between seasons (b), between sites during dry season (c) and wet season (d). Given are mean of 500 randomizations and 95\% lower confidence intervals (LCl) for the species rich site/season and the upper confidence intervals $(\mathrm{UCl})$ for the species poor site/season. Differences were considered to be significant if the $95 \% \mathrm{LCl}$ of the species rich site did not overlap with the $\mathrm{UCl}$ of the poor site

Table 3: Observed $\left(\mathrm{S}_{\mathrm{obs}}\right)$ and rarefied $\left[\mathrm{S}_{\text {rare }}(95 \% \mathrm{Cl})\right]$ species richness of the three sets of guilds in the grazed and ungrazed sites

\begin{tabular}{|c|c|c|c|c|c|}
\hline Guild type & Guild category & site & No. individuals & $\mathrm{S}_{\text {obs }}$ & $\mathrm{S}_{\text {rare }}(95 \% \mathrm{Cl})^{*}$ \\
\hline \multirow{4}{*}{ habitat } & \multirow{2}{*}{ specialist } & ungrazed & 1173 & 17 & $16.8(16.7-16.9)^{a}$ \\
\hline & & grazed & 765 & 11 & $11.0(9.7-12.3)^{b^{\prime}}$ \\
\hline & \multirow{2}{*}{ generalists } & ungrazed & 83 & 7 & $7.0(4.6-9.4)^{\mathrm{a}}$ \\
\hline & & grazed & 1545 & 14 & $8.4(5.6-11.1)^{a}$ \\
\hline \multirow{4}{*}{ diet } & \multirow{2}{*}{ insectivore } & ungrazed & 525 & 13 & $13(11.7-14.3)^{a}$ \\
\hline & & grazed & 765 & 11 & $10.6(9.5-11.6)^{b}$ \\
\hline & \multirow{2}{*}{ others } & ungrazed & 731 & 11 & $11.0(10.1-11.9)^{a}$ \\
\hline & & grazed & 1545 & 14 & $12.6(9.8-14.4)^{a}$ \\
\hline \multirow{4}{*}{ conservation priority } & \multirow{2}{*}{ High } & ungrazed & 736 & 9 & $8.8(7.5-10.1)^{a}$ \\
\hline & & grazed & 710 & 5 & $5.0(5.0-5.0)^{\mathrm{b}}$ \\
\hline & \multirow{2}{*}{ low } & ungrazed & 520 & 15 & $15.0(14.1-15.9)^{a}$ \\
\hline & & grazed & 1700 & 20 & $16.7(13.4-20.0)^{a}$ \\
\hline
\end{tabular}


Addisu Asefa et al.,

Sci. Technol. Arts Res. J., April-June 2015, 4(2): 112-121
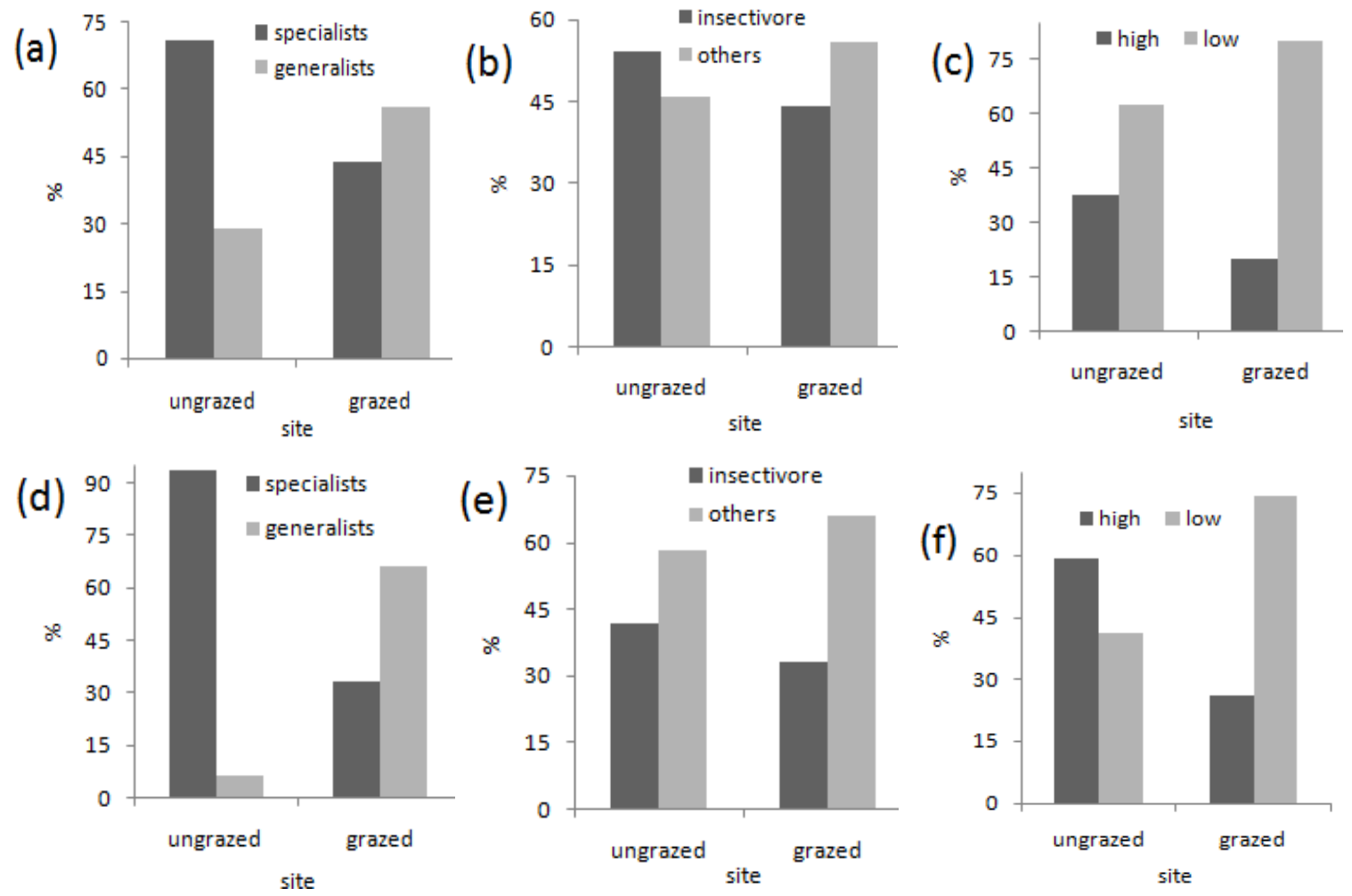

Figure 3: The relative contribution (measured as a percentage) each guild makes to the species richness (a-c) and abundance (d-f) of the bird assemblages in the ungrazed and grazed sites [(a) and (d) = habitat guilds, (b) and

$(\mathrm{e})=$ feeding guilds, and $(\mathrm{c})$ and $(\mathrm{f})=$ conservation importance guilds)] .

Analysis of similarity (ANOSIM) revealed significant differences in bird assemblages composition between sites both across seasons (Global $\mathrm{R}=0.890, P<0.05$ ) and when seasons were considered separately (dry season, $R$ $=, 0.881$; wet season, $\mathrm{R}=0.900$, in both cases, $P<0.05$; Figure 4). Furthermore, assemblages were also significantly different between seasons both across sites $(\mathrm{R}=0.506, P<0.05)$ and within site (ungrazed site, $\mathrm{R}=$ 0.356; grazed site, $\mathrm{R}=0.656$. in both cases, $P<0.05$; Figure 4).
Effects of Grazing-induced Vegetation Change on Bird Assemblage

The result of BEST analysis revealed that the assemblages of both the ungrazed and grazed sites showed significant relationships with the vegetation variables considered. The ungrazed site assemblage was best correlated with heights of shrub and grass $(R=$ $0.405, P<0.05)$ and that of the grazed site with heights of herb and grass and cover of herb and bare ground $(R=$ $0.324, P<0.05)$.

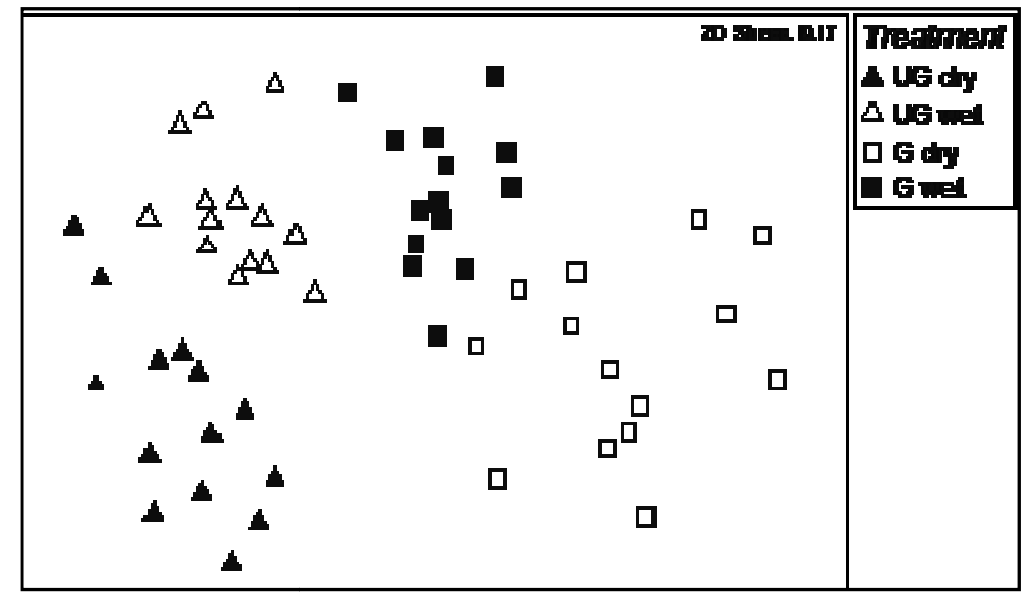

Figure 4: Non-metric multi-dimensional scaling (nMDS) ordination of bird assemblages from each sampling point in the grazed and ungrazed sites across wet and dry seasons in the Afromontane grasslands of the Bale mountains (UG dry = ungrazed site dry season; UG wet = ungrazed wet season; G dry = grazed site dry season; and, G wet $=$ grazed site wet season). 


\section{DISCUSSION}

Our study demonstrated that, depending on season, livestock grazing in Ethiopian Afromontane grasslands to have neutral, positive or negative effects on overall species richness, abundance and composition of bird assemblages. Non-significant difference was found between grazed and ungrazed sites in species richness both across seasons and in dry season. In contrast, bird assemblage abundance during dry season and across seasons was significantly greater in the grazed site than the ungrazed site. These nearly equal richness and greater abundance in the grazed site could be as a result of the persistence of some typical grassland bird species, together with the invasion/colonization of non-grassland (generalist, see discussion below) avian species from the surrounding cultivation fields and woodlands into the grazed grassland site.

The adversity of livestock grazing on birds of the area was more revealed to be altering assemblage composition (species evenness and guild composition) than decreasing overall richness and abundance. As predicted, our study found a higher richness of species considered to be grassland/shrub-land habitat specialist, insectivore feeding and high conservation priority guilds in ungrazed site. These findings were further supported by the relative percentage contributions they made to the overall richness and abundance of bird assemblage in each respective site. Consequently, bird assemblages of the two sites were found to be significantly distinct. There are several reasons why this might be the case. Grazing affects birds in several ways, including change in vegetation structure and food availability and abundance (Muchai et al., 2002; Barbaro and van Halder, 2009, Rahmig et al., 2009). These effects, depending on season, grazing intensity and species-specific ecological traits (e.g. preferred habitat/dietary requirements), can be either positive or negative (Whittingham and Devereux, 2008; see also discussion below). The assumption is that grazing reduces vegetation height and cover and the abundance and availability of food in tall grass/shrubby vegetation (Jensen, 1985; Mclntyre et al., 2003; Tallowin et al., 2005). Thus, while bird species that prefer tall vegetation habitat for feeding and reproduction respond negatively to grazing, those species preferring open habitat and short grass respond positively (Martin and Possingham, 2005; Evans et al., 2006; Whitehorn et al., 2011). Thus the dissimilarity in assemblage composition found between the two sites can generally be explained to be as a result of varying responses of different species to grazing-induced habitat changes.

Seasonal difference in habitat variables was nonsignificant, which may be expected as grazing in the area takes place throughout the year, perhaps indicating that the effect of grazing on the vegetation variables considered in this study to be constant. This finding seems to be unexpected, coupled to the significant difference found in bird assemblage composition between seasons, given our argument that any difference found between sites or seasons to be attributed to difference in vegetation structure. This lack of consistence in variations of bird assemblage composition and habitat variables between seasons may suggest that there might be other important habitat/environmental variables that might vary with season and affects bird assemblage composition, which we should have to measure. Habitat variables that potentially influence the occurrence and abundance of bird species, but we failed to measure, include plant phenology such as availability and abundance of flowers and seeds. This supposition could hold true as both specialist (e.g. sunbirds) and opportunistic [e.g. baglafecht weaver (Ploceus baglafecht) and slender-billed starling (Oegnathus tenuirostris)] nectar-feeding bird species were not encountered during dry season survey when flowers were not available (see Appendix). These species were however abundant in both sites during wet season survey when Knophofia foliosa plants bear flowers.

In addition to its influence on vegetation phenology, season, independently or interactively with grazing, affects the presence and abundances of other birds' feeding resources (e.g. invertebrates; see also, Gibson et al., 1992; Buckingham et al., 2004). For example, the abundance of wattled ibis (Bostrychia carunculata) the most abundant insectivore bird species in the grazed site, was markedly high during wet season compared to dry season (620 vs. 245; see Appendix). However, we do not have any empirical evidence for such seasonal variations in invertebrate richness and abundance in our study sites to attribute our results to such variations, and further research is required to test if this is one of the possible causes for the observed assemblage differences. Nonetheless, regardless of season, bird assemblages of the two sites showed positive correlations with shrub height and/or grass height. Given that grassland specialist and/or high conservation priority species were found to be negatively impacted by grazing, coupled to the findings that these vegetation features are those most adversely affected by grazing in the area (Yosef Mamo et al., 2014) the observed bird-habitat relationships have significant conservation implications. Allowing livestock grazing in the protected (i.e. currently ungrazed site) site on the future will lead to loss of several grassland specialist and/or high conservation significant species.

\section{CONCLUSIONS}

This study showed that livestock grazing is neither equally beneficial nor harmful to all bird species, and the responses of birds to grazing depend on species-specific habitat and/or food preferences. Although overall assemblage species richness and/or population abundance was nearly equal between sites, grassland habitat specialist, insectivore and/or high conservation priority species were negatively affected due to grazing while the other guilds showing the opposite response. Thus the effect of grazing on birds of the area is changing assemblage composition rather than resulting into declined assemblage species richness. Given that the effects of grazing could be positive or negative, future studies focusing on such impact assessment should be undertaken and evaluated in terms of the conservation goal of the habitat in question (e.g. increasing or maintaining of overall assemblage richness and abundance, or of groups of species typical to that habitat; or of species with high conservation priority). This approach (comparison of the responses of different guilds) has enabled us uncover the effect of grazing which was obscured while the analyses/comparisons were made at assemblage level.

\section{Acknowledgments}

We thank Daniel Tilaye and Girma Bekele for their assistance during the field work. This study was conducted with a financial support provided by Wondo Genet College of Forestry and Natural Resources 
Addisu Asefa et al.,

Hawassa University, Ethiopia. We also thank the Ethiopian Wildlife Conservation Authority and the Bale Mountains National Park for the research permission provided.

\section{Conflict of Interest}

All the authors don't have any conflict of interest

\section{REFERENCES}

Addisu Asefa (2007). Birds of Bale Mountains National Park, Southeast Ethiopia. Walia 25: 22-33.

Addisu Asefa (2011). Mammals of the Bale Mountains National Park, Ethiopia: a compiled and annotated checklist. Walia-Special Edition on the Bale Mountains 314.

Addisu Asefa Mitiku (2013). Afromontane avian assemblages and land use in the Bale Mountains of Ethiopia: patterns, processes and conservation implications. MSc Dissertation, University of Pretoria, Pretoria. 118 pp.

BirdlLife International (2014). Species factsheets. [Available online: http://www.birdlife.org/datazone/info/spchabalt; accessed 20 January 2014].

Barbaro, L., van Halder, I. (2009). Linking bird, carabid beetle and butterfly life-history traits to habitat fragmentation in mosaic landscapes. Ecography 32: 321-333.

Bleher, B., Uster, D., Bergsdorf, T. (2006). Assessment of threat status and management effectiveness in Kakamega Forest, Kenya. Biodiversity and Conservation 15: 1159-1177.

Brooks, T.M., Mittermeier, R. A., da Fonseca, G. A. B., Gerlach, J., Hoffmann, M., Lamoreux, J. F., Mittermeier, C. G., Pilgrim, J. D., Rodrigues. A. S. L. (2006). Global biodiversity conservation priorities. Science 313: 58-63.

Buckingham, D.L., Atkinson, P.W., Rook, A.J. (2004). Testing solutions in grass-dominated landscapes: a review of current research. Ibis 146: 2-163.

Chown, S.L. (2010). Temporal biodiversity change in transformed landscapes: a southern African perspective. Philosophical Transactions of the Royal Society (B) 365: 3729-3742.

Clarke, K.R., Gorley, R.N. (2006). PRIMER V6: User Manual/Tutorial. PRIMER-E, London.

Colwell, R. K. (2009). EstimateS 8.2 User's Guide. [Available online: http://purl.oclc.org/estimates or http://viceroy.eeb.uconn.edu/estimates; accessed on 05 January 2015]

Evans, D.M., Redpath, S.M., Evans, S.A., Elston, D.A., Gardner, C.J., Dennis, P., Pakeman, R.J. (2006). Low intensity, mixed livestock grazing improves the breeding abundance of a common insectivorous passerine. Biology Letters 2: 636-638.

EWNHS (Ethiopian Wildlife and Natural History Society) (1996). Important Bird Areas of Ethiopia: a first inventory. EWNHS, Addis Ababa, Ethiopia. Pp. 1-15.

Fuller, R.J., Gough, S.J. (1999). Changes in sheep numbers in Britain: implications for bird populations. Biological Conservation 91: 73-89.

Gibson, C.W.D., Brown, V.K., Losito, L., McGavin, G.C. (1992). The response of invertebrate assemblies to grazing. Ecography 15: 166-176.

Gotelli, N., Colwell, R. K. (2001). Quantifying biodiversity: Procedures and pitfalls in the measurement and
Sci. Technol. Arts Res. J., April-June 2015, 4(2): 112-121 comparison of species richness. Ecology Letters 4: 379391.

Gove, A.D., Hylander, K., Sileshi Nemomsa, Anteneh Shimelis, Wolde Enkossa (2013). Structurally complex farms support high avian functional diversity in tropical montane Ethiopia. Journal of Tropical Ecology 29: 87-97.

Heikkinen, R., Luoto, M., Virkkala, R., Rainio, K. (2004). Effects of habitat cover, landscape structure and spatial variables on the abundance of birds in agricultural-forest mosaic. Journal of Applied Ecology 41: 824-835.

Hoekstra, J. M., Boucher, T. M., Ricketts, T. H., Roberts, C. (2005). Confronting a biome crisis: global disparities of habitat loss and protection. Ecology Letters 8: 23-29.

Jensen, A. (1985). The effect of cattle and sheep grazing on salt marsh vegetation at Skallingen, Denmark. Vegetation 60: 37-48.

Kimball, S., Schiffman, P. M. (2003). Differing effects of cattle grazing on native and alien plants. Conservation Biology 17: 1681-1693.

Magurran, A.E. (2004). Measuring biological diversity. Blackwell Science Ltd, Malden, USA. 256pp.

Martin, T.G., Possingham, H. P. (2005). Predicting the impact of livestock grazing on birds using foraging height' data. Journal of Applied Ecology 42: 400-408.

Mclntyre, S., Heard, K.M., Martin, T.G. (2003). The relative importance of cattle grazing in sub-tropical grasslands does it reduce or enhance plant biodiversity? Journal of Applied Ecology 40: 445-457.

Mckee, J. (2005). Ethiopia: country environmental profile. The European Union, Addis Ababa, Ethiopia. 64 pp.

Muchai, M., Lens, L., Bennun, L. (2002). Habitat selection and conservation of sharp's long-claw (Macronyx sharpei), a threatened Kenyan grassland endemic. Biological Conservation 105: 271-277.

Mulwa, R.K., Böhning-Gaese, K., Schleuning, M. (2012). High Bird Species Diversity in Structurally Heterogeneous Farmland in Western Kenya. Biotropica 44: 1-9.

Newbold, T., Scharlemann, J.P.W., Butchart, S.H.M. Sekercioglu, C.., Alkemade, B., Booth, H., Purves, D.W. (2014). Ecological traits affect the response of tropical forest bird species to land-use intensity. Proceedings of the Royal Society (B) 280: 2012-2131.

Newton, A.C. (2007). Forest ecology and conservation: a handbook of techniques in ecology and conservation series. Oxford University Press, Oxford, UK. 454 pp.

OARDB (2007). Bale Mountains National Park General Management Plan. Oromia Agriculture and Rural Development Bureau, Addis Ababa, Ethiopia. 167 pp.

Quinn, G.P., Keough, M.J. (2002). Experimental design and data analysis for biologists, 1st edn. Cambridge University Press, Cambridge, UK. 537 pp.

Rahmig, C.J., Jensen, W.E., With, K.A. (2009). Grassland bird responses to land management in the largest remaining tallgrass prairie. Conservation Biology 23:42032.

Rasran, L., Vogt, K., Jensen, K. (2007). Effects of topsoil removal, seed transfer with plant material and moderate grazing on restoration of riparian fen grasslands. Applied Vegetation Science 10: 451-460.

Seavy, N. E. (2009). Bird use of banana plantations adjacent to Kibale national park, Uganda: Evaluating the 


\section{Addisu Asefa et alo,}

conservation value of a matrix habitat. Journal of East African Natural History 98: 211-222.

Şekercioğlu, C. H., Ehrlich, P.R., Daily, G. C., Aygen, D., Goehring, D., Sandí, R.F. (2002). Disappearance of insectivorous birds from tropical forest fragments. Proceedings of National Academy of Science of USA 99: 263-267.

Stephens, P.A., d'Sa, C.A., Sillero-Zubri, C., Williams, N.L. (2001) Impact of livestock and settlement on the large mammalian wildlife of Bale Mountains National Park, Southern Ethiopia. Biological Conservation 100: 307-322.

Tallowin, J., Rook A.J., Rutter S.M. (2005). Impact of grazing management on biodiversity of grasslands. Animal Science 81: 193-198.

Whitehorn, I.B.J., Harrison, M.. Mahony, N.A., Robinson, P., Newbury, A., Green. D.J. (2011). Effects of cattle grazing on birds in Interior Douglas-fir (Pseudotsuga menziesii)
Sci. Technol. Arts Res. J., April-June 2015, 4(2): 112-121

forests of British Columbia. BC Journal of Ecosystem Management 12: 1-17.

Whittingham, M.J., Devereux, C.L. (2008). Changing grass height alters foraging site selection by wintering farmland birds. Basic and Applied Ecology 9: 779-788.

Williams, S., Vivero Pol, J.L., Spawls, S., Anteneh Shimelis, Ensermu Kelbessa (2004). Ethiopian Highlands. In: (Mittermeier, R.A., Gill, P.R., Hoffmann, M., Pilgrim, J., Brooks, T., Mittermeier, C.G., Lamoreux, J., da Fonseca, G.A.B. Eds.). Hotspots revisited, pp 262-273. CEMEX Publisher, Washington, D.C. USA.

Yosef Mamo, Girma Mengesha, Addisu Asefa (2014). Abundance and habitat preference of the near-threatened Ethiopian endemic Abyssinian long-claw (Macronyx flavicollis) bird in the northern montane grasslands of the Bale Mountains. Journal of Development Research 4: 1887-1893. 